\title{
Re-use of spent cell culture medium in pilot scale and rapid preparative purification with membrane chromatography
}

\author{
U. Riese *, D. Lütkemeyer, R. Heidemann, H. Büntemeyer, J. Lehmann \\ Instiute for Cell Culure Technology. L'mucersity of Bielefeld. P.O. Box 100131,33 501 Bielefeld. Germany
}

(Received 3 May 1993: revision accepted 28 June 1993)

\begin{abstract}
Based on experiments in bench scale, a recycling of spent cell culture medium was performed in a 100-1 pilot scale bioreactor. The cell cultivation has been done as a repeated batch procedure after the initial batch in the following four repeated batches spent medium from the previous batch was partially re-used. After microfiltration and ultrafiltration a part of the filtrate was mixed with a concentrate of amino acids and glucose, sterile filtered and subsequently filled back into the bioreactor. Up to $65 C^{\circ}$ of the harvested cell- and product-free spent medium was re-used in each repeated batch. This procedure results in a saving of pure and waste water volume and saving of supplemented proteins as transferrin, insulin and lipoproteins and, therefore, also in a reduction of the production costs.

A strongly acidic membrane ion exchanger was evaluated for the ability to purify the monoclonal antibodies from the pilot scale cultivation. Within minutes. gram quantities of product could be purified in a high flux system, especially developed for this purpose, achieving purities of $80{ }^{\circ} c$. The capacity of the acidic membrane ion exchanger was found in former investigations to be $1 \mathrm{mg} \mathrm{cm}^{-2}$ with recoveries up to $96^{\tau} \mathrm{c}$. Final purification was carried out by gel column filtration.
\end{abstract}

Key words: Monoclonal antibody: Economy: Large scale: Medium; Membrane ion exchanger: Re-use: Waste water minimizing

\section{Introduction}

During the first period of cell culture used for industrial processes attempts have already been made to minimize the costs for medium. Mizrahi and Avihoo (1977) tried to re-use serum contain-

\footnotetext{
* Corresponding author (present address): U. Riese, $c$, o Mrs. Dr. S.C. Boork, Kabi Pharmacia. Bio Science Center. Strandbergsgatan 49, S-112 87 Stockholm. Sweden.
}

ing spent cell culture medium after supplementation of the amino acids consumed. They re-used $100^{\circ} \mathrm{C}$ of the spent medium, but the medium could only be recycled once because cell growth was negatively influenced. Therefore, this procedure was not introduced into industrial production processes. Interpreting the growth inhibition reported by Mizrahi and Avihoo caused by an accumulation of toxic substances, Kempken et al. (1991) proposed a partial medium recycling; this system was called, medium cycling bioreactor 
(MCB). In a 2-1 scale reactor with serum-free medium. it could be shoun that it is possible to continue to re-use the spent medium as long as the percentage of re-used medium was less than $75 \%$ of the total volume per recycling step (Munzert. 1992).

In cell culture processes the re-use of medium allow's the production costs to drop because the volume of medium is less than for conventional processes. To avoid inhibitory effects caused by an accumulation of toxic metabolites in the spent medium the re-used part of the medium was diluted with fresh medium.

This strategy is schematically depicted in Fig. 1. The liquid stream out of the bioreactor was substituted by an equal volumetric stream consisting of a supplemented medium concentrate. (Ising this strategy. possibly accumulated inhibitors may be diluted down to non harmful concentrations. In contrast to small-scale, where continuous processes are very common. for the large-scale experiments described in this paper a repeated batch process in 110-1 working volume has been used. The flow scheme of the apparatus employed for this process is given in Fig. 2 .

Cells were separated by a semicontinuous centrifuge which was linked to the bioreactor in a way such that it was possible to disconnect it from the bioreactor for cell harvest $w$ ithout interrup-

\section{Medium Recycling Process}

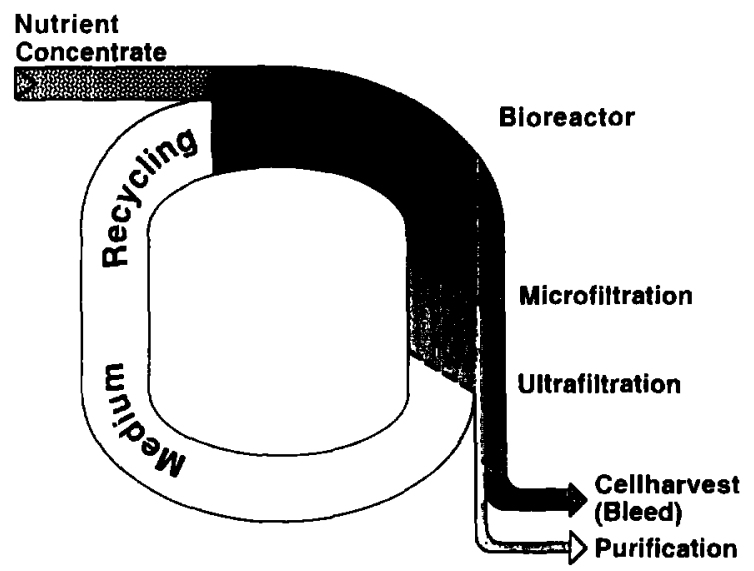

Fig. I Liquid flou scheme of the recyclıng process. The output streams for cell harrest and purification are substituted hy a fresh medium nutrient concentrate.

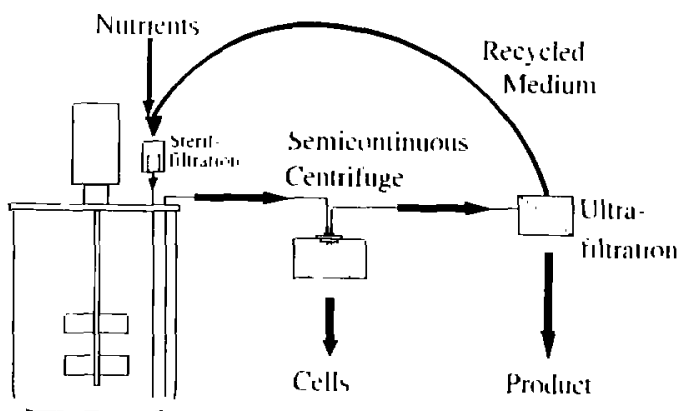

110 I Bioreachor

Fig 2. Flow scheme of the esperımental selup. The cells were separated in a semicontinuous centrifuge. The product wa separated irom the sell free medium by ultrafiltration. The UF permeate was supplemented with nutrients. This wlume was then sterilfiltered directly back into the horeactor.

tion of the cultivation process. The product. a monoclonal antibody (mAb), was separated trom the cell-free supernatant stream of the centrifuge by crossflow ultrafiltration. The filtrate of the UF was recycled batchwise.

For the purification and preparation of proteins, peptides and enzymes. ion exchange is a common technique. However, using classical soft gels or porous particle media as a matrix results in a limitation arising from the restriction of mass transport in these diffusion-dominated systems. A different approach is the attachment of functional groups to the inner surfaces of synthetic microporous membranes. The main advantage of using membranes as a matrix is the fact that the mass transport is convective and, therefore, avoids the aforementioned limitation of classical matrices. Other interesting features in addition to the high flux rate include: high adsorption rates and binding velocities: no problems arising from channeling. bed shift or bed collapse: the ease of scale up and the comfort of using a prepacked stabilized matrix.

\section{Materials and methods}

\subsection{Process procedure}

After inoculating and filling the bioreactor, the first batch was performed. When cells reached 
stationary phase the batch was terminated by pumping the reaction mixture out of the bioreactor. A small amount was left in the bioreactor as inoculum for the following repeated batch. The spent medium was passed through a centrifuge for cell separation and the supernatant was given to a crossflow ultrafiltration system, where the product was removed. Then the UF filtrate was analyzed for its amino acid and glucose contents. The lacking amounts of amino acids and glucose were calculated and added as concentrate which was finally mixed with the UF filtrate. For the preparation of the concentrate, amino acids and glucose were dissolved in fresh medium. The complete volume was sterile filtered and fed back into the bioreactor. During the subsequent cell grow'th period the centrifuge was disconnected. cells were harvested from the rotor. which was then cleaned, autoclaved and relinked to the system for the cell harvest within the next repeated batch.

At the beginning of the experiment the ultrafiltration unit was initially steam sterilized inline. It was not cleaned or sterilized between the recycling steps.

\subsection{Materials}

The bioreactor was a BIOSTAT $100 \mathrm{I}$ from $\mathrm{B}$. Braun (Biotech International, Melsungen, Germany). This bioreactor was equipped with a fixed silicone tube for bubble-free aeration and a marine-type impeller for mixing. During cultivation. temperature was set at $37^{\circ} \mathrm{C}, \mathrm{pH}$ to 7.10 and the stirrer speed to $30 \mathrm{rpm}$. The dissolved oxygen concentration was controlled at $40^{\circ} \%$ air saturation.

Cell separation was performed with a Biofuge 17 RS with an autoclavable titan rotor 8575 (both Heraeus, Osterode/Harz, Germany). The crossflow system for ultrafiltration was a Sartocon II system (Sartorius AG. Göttingen, Germany) equipped with a single Ultrasart module (filter material: Polysulfon, filtration area: $0.7 \mathrm{~m}^{2}$. cut off: $100 \mathrm{kDa}$ ). Large media volumes were mixed in a stirrer-equipped stainless steal buffer tank (B. Braun Biotech International, Melsungen, Germany).
The cell line used in this experiment was a mouse-mouse hybridoma secreting a monoclonal antibody ( $m A b)$ type $I_{g G_{1}}$, kindly provided by KabiPharmacia (Sweden). The medium was sterile filtered with a filtration system consisting of two filters in line with $0.45 \mu \mathrm{m}$ and $0.2 \mu \mathrm{m}$ pore size, respectively (Sartorius AG. Göttingen, Germany). This system was sterilized inline by steam. The filter integrity was checked by a forward flow test using the Sartocheck II device (Sartorius AG. Göttingen, Germany) before and after each filtration step.

Two samples per day were taken from the bioreactor and analyzed as follows: Living and dead cell numbers were microscopically analyzed after Trypan blue exclusion: the free amino acids in the samples were analyzed with HPLC (System 400, Kontron, Eching, Germany) using the OPA method (Büntemeyer, 1988); antibody concentration was analyzed using a kinetic sandwich ELISA. For fast antibody quantification a new analyzing system based on a affinity column (Abicap. Abion. Benediktbeuern. Germany) has also been used.

To separate the cells from the reaction mixture it was passed through the centrifuge with a flow rate of $300 \mathrm{ml} \mathrm{min}{ }^{-1}$. In the first recycling step. the cell separation was performed at a rotor speed of $6500 \mathrm{rpm}(3543 \times g)$. The resulting clearance rate was $97^{\circ} c$. In the following steps the rotor speed was set to $9000 \mathrm{rpm}(6792 \times \mathrm{g})$ but no increase of clearance had been observed.

The purification of the antibodies was performed with Sartobind membrane ion exchanger prototypes. which were kindly supplied by Sartorius AG (Göttingen, Germany). The strongly acidic membrane ion exchanger (MIEX) with a pore size of $0.45 \mu \mathrm{m}$ and a membrane thickness of $170-190 \mu \mathrm{m}$ was folded into the module. The area of the module was $1400 \mathrm{~cm}^{2}$. The membrane is autoclavable and stable over a range of $\mathrm{pH}$ 2-13. The maximum operation pressure was + bar.

In order to bind proteins to the ion exchanger, the conductivity of the supernatant had to be reduced from $13 \mathrm{mS} \mathrm{cm}{ }^{-1}$ (normal cell culture medium) to $1.3-1.8 \mathrm{mS} \mathrm{cm}^{-1}$ (Fig. 3). In addition. the supernatant was first concentrated by 


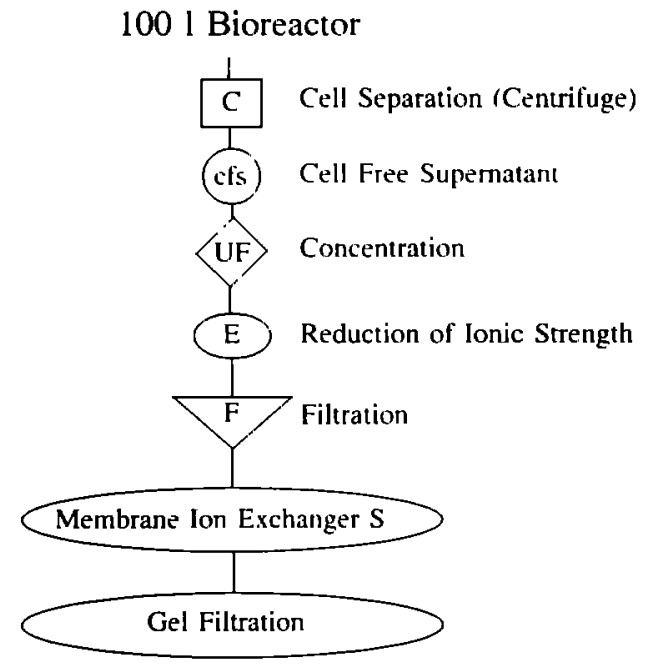

Fig. 3. Purification scheme of a batch of the 100-I cultivation. After cell separation the supernatant was concentrated by ultrafiltration. The reduction of ionic strength was performed by electrodialysis. After it filtration step the supernatant was purıfied by membrane chromatography. Final purification was carried out by gel filtration. ultrafiltration. To achieve this reduction in conductivity, an electrodialysis system (StanTech GmbH. Geesthacht, Germany) was used. After adjusting the $\mathrm{pH}$ to 5.8 and a filtration step $(0.2 \mu \mathrm{m})$. the supernatant was passed through the S-type membrane ion exchanger using the high flux system (HFS; Fig. 4). The product was eluted from the membrane by a shift in salt concentration.

For the acidic ion exchanger the following buffers were used: buffer A: $10 \mathrm{mM}$ Na-phosphate $+10 \mathrm{mM} \mathrm{NaCl} \mathrm{pH} 5.8$; buffer $B: 10 \mathrm{mM}$ $\mathrm{Na}$-phosphate $+250 \mathrm{mM} \mathrm{NaCl} \mathrm{pH} 5.8$.

For cleaning and regeneration $0.2 \mathrm{M} \mathrm{NaOH}$ $\left(60^{\circ} \mathrm{C}, 20 \mathrm{~min}\right)$ was used. The membranes could be cleaned without loss of binding capacity and were regenerated by washing with buffer $A$.

Final purification was carried out using a preparative gel filtration column (Superdex 200 PG, Pharmacia Biosystems, Freiburg, Germany) with $600 \mathrm{ml}$ gel volume. A $20 \mathrm{mM}$ phosphate buffer containing $150 \mathrm{mM} \mathrm{NaCl}$ was used. The

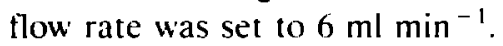

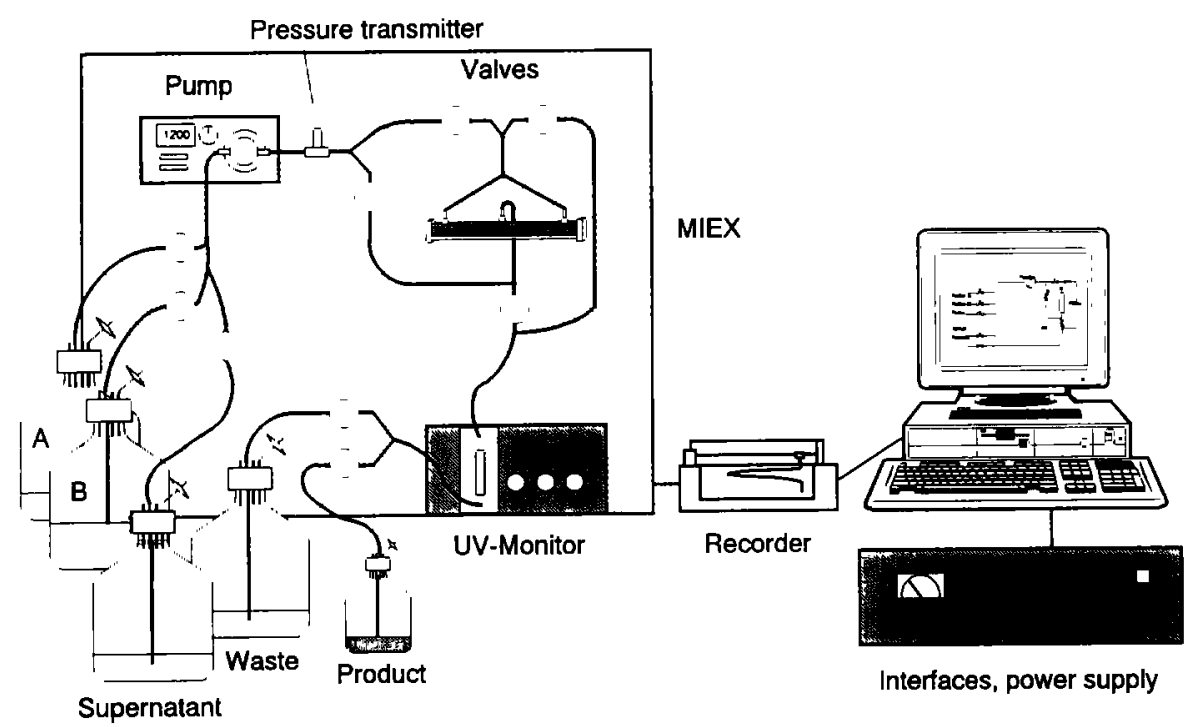

Fig. 4. High tlux system consisting of a gear wheel pump. a L' monitor, a pressure transmitter and special valves. A personal computer was equipped with interfaces for A, D, D, A and TTL signal transfer. Specially developed softurare offers the opportunity to control the valves and to monitor the U' and pressure signals. thus enabling complete automatization. The system uas developed for optimal use of the preparative membrane ion exchanger units and allous flow rates up to $1200 \mathrm{ml}^{\mathrm{min}}{ }^{-1}$ and a maximum pressure of 1.2 bar. 


\subsection{Medium preparation}

The cell line was grown in a serum-free basal medium based on a 1:1 mixture of DMEM/ Ham's F 12 supplemented with $50 \mu \mathrm{M}$ ethanolamine, $2 \mathrm{mM}$ sodium pyruvate and the following proteins: $10 \mathrm{mg} \mathrm{I}^{-1}$ bovine insulin (Sigma, Deisenhofen, Germany) $10 \mathrm{mg} \mathrm{l}^{-1}$ human transferrin (Behringwerke AG. Marburg, Germany) Fe-saturated, $0.5 \mathrm{~g} \mathrm{I}^{-1}$ bovine serum albumin (Serva, Heidelberg. Germany) complexed with $2 \mathrm{mg}$ oleic acid (Serva) and $1.0 \mathrm{ml} \mathrm{l}^{-1}$ Pentex Excyte I (Bayer Diagnostics, München, Germany; Büntemeyer et al., 1991). To avoid nutrient limitation at high cell densities for the initial batch this medium was additionally supplemented with several amino acids and $11 \mathrm{mM}$ glucose (Table 1 ).

At the end of every repeated batch, a culture medium sample was taken and analyzed for amino

Table 1

Amino acid and glucose concentrations in the basal medium (DMEM/Ham's F12), the supplements and the optimized medium for high cell density cultures

\begin{tabular}{|c|c|c|c|}
\hline Substrate & $\begin{array}{l}\text { Basal } \\
\text { medium } \\
(\mu \mathrm{M})\end{array}$ & $\begin{array}{l}\text { Amount } \\
\text { of added } \\
\text { supplements } \\
(\mu \mathrm{M})\end{array}$ & $\begin{array}{l}\text { Optimized } \\
\text { medium } \\
\text { for hıgh cell } \\
\text { densities } \\
(\mu \mathrm{M})\end{array}$ \\
\hline His & 150.2 & 143 & 293.2 \\
\hline Gln & 2469.6 & 6566 & 9035.6 \\
\hline Gly & 249.7 & - & 249.7 \\
\hline Arg & 697.7 & 332 & 1029.7 \\
\hline Tyr & 313.7 & 220.7 & 534.4 \\
\hline Trp & 44.2 & 146.7 & 190.9 \\
\hline Met & 115.5 & 268.1 & 383.6 \\
\hline Val & 449.3 & 511.9 & 961.2 \\
\hline Phe & 214.7 & 90.8 & 305.5 \\
\hline Ile & 414.4 & 457.3 & 871.7 \\
\hline Leu & 449.4 & 457.3 & 906.7 \\
\hline Lys & 497.4 & 246.3 & 743.7 \\
\hline Asn & 49.96 & - & 49.96 \\
\hline $\mathrm{Ala}$ & 50.5 & - & 50.5 \\
\hline Asp & 50.3 & 50.3 & 100.6 \\
\hline Cys-Cys & 203.1 & 208 & 411.1 \\
\hline Glu & 49.96 & - & 49.96 \\
\hline Pro & 150.0 & - & 150.0 \\
\hline Ser & 249.8 & - & 249.8 \\
\hline Thr & 448.9 & 419.8 & 868.7 \\
\hline Glucose & 18149.3 & 11098.8 & $292+8.1$ \\
\hline
\end{tabular}

acid and glucose concentrations. The results were used for the calculation of the amounts of amino acids and glucose to be added to the fresh medium to substitute these consumed nutrients. After adding this amount at the beginning of the following repeated batch, the concentrations in the reactor were again nearly the same as at the beginning of the previous one. In contrast to this procedure, the amount of proteins to be added to every repeated step was not calculated from its consumption. It was just added into the fresh medium concentrate at concentrations according to the figures mentioned above.

\section{Results}

The experiment was divided in an initial batch and four repeated batch cultivations. After the first batch. the four repeated batches were performed with recycled medium, they are called recycling processes. Each recycling process was started with an inoculum taken from the previous batch. The added volume consisted of two parts, a part of fresh medium concentrate and a part of recycled medium. For the calculation of the percentage of the recycled medium, summarized in Table 2, the recycled medium was regarded as the sum of the UF filtrate volume and the remaining medium from the previous batch.

The inoculum for the first batch culture was produced with a 2-I perfusion culture. The starting volume in the $100 \mathrm{I}$ reactor was $35 \mathrm{I}$. After $1 \mathrm{~d}$, the bioreactor was filled up to $55 \mathrm{I}$ and after $2 \mathrm{~d}$ to $110 \mathrm{l}$. The cell density was then $3.2 \times 10^{5}$ viable cells per $\mathrm{ml}$. The whole time course of the overall process is depicted in Fig. 5.

The initial batch was finished after $5.2 \mathrm{~d}$ of cultivation and reached a cell number of $2.6 \times 10^{6}$ viable cells per $\mathrm{ml}$ and runs at $112 \mathrm{I}$ constant working volume. The first repeated batch was performed with $63^{\circ}$ of spent medium. The viable cell number decreased at $1.3 \times 10^{\circ}$ viable cells per ml, not caused by a limitation of amino acids or glucose. As can been seen from Fig. 6, the supply of amino acids was sufficient at this time of the cultivation. This batch was finished after a 
Table :

Composition of the reactor working volume

\begin{tabular}{|c|c|c|c|c|c|}
\hline $\begin{array}{l}\text { Culture } \\
\text { mode }\end{array}$ & $\begin{array}{l}\text { Ino- } \\
\text { culum } \\
\text { (I) }\end{array}$ & $\begin{array}{l}\text { Recycled } \\
\text { UF } \\
\text { filtrate } \\
\text { (1) }\end{array}$ & $\begin{array}{l}\text { Fresh } \\
\text { medium } \\
\text { (l) }\end{array}$ & $\begin{array}{l}\text { Reactor } \\
\text { working } \\
\text { volume } \\
\text { (I) }\end{array}$ & $\begin{array}{l}\text { Recycled } \\
\text { spent } \\
\text { medium } \\
(\mathrm{C}) \mid\end{array}$ \\
\hline I batch & 55 & - & 55 & 110 & - \\
\hline I recyclıng & 10 & 55 & 41 & 112 & 6.3 \\
\hline 2 recycling & 29 & +2 & $3, i$ & 104 & 65 \\
\hline 3 recscling & 31 & 44 & +1 & 116 & 65 \\
\hline 4 recycling & 26 & 39 & 51 & 116 & in \\
\hline
\end{tabular}

period of 3.5 to $8.7 \mathrm{~d}$ of overall cultivation time at a cell number of $7.5 \times 10^{5}$ viable cells per $\mathrm{ml}$. The second recycling process was run at a total volume of 109 I and started with $1.0 \times 10^{\circ}$ viable cells per $\mathrm{ml}$ now containing $65^{\circ} c$ of recycled medium. This batch was finished after $12.7 \mathrm{~d}$ overall cultivation time with a viable cell number of $8.4 \times 10^{5} \mathrm{ml}^{-1}$. For the third recycling step also $65 \%$ spent medium was recycled. However. this process was started with $2.2 \times 10^{5}$ viable cells per $\mathrm{ml}$ and run at 116 I total volume. After $2.6 \mathrm{~d}$ batch time the bioreactor was harvested; the cell number was then $1.4 \times 10^{\circ}$ viable cells per ml. In the fourth recycling process the amount of medium was decreased to $56^{\circ} \%$. This batch was
Table ?

Apparent specific grouth rates and specific antibody production rates for the initial batch and the recycling processes

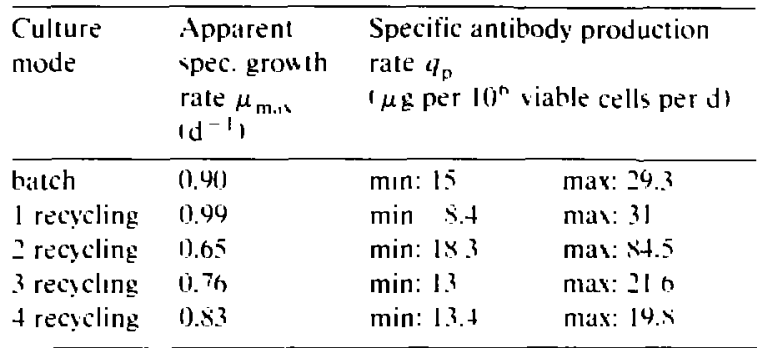

started with $2.45 \times 10^{\circ}$ viable cells per $\mathrm{ml}$. The experiment was finished after $19.7 \mathrm{~d}$ overall cultivation time. The viable cells reached a density of $1.7 \times 10^{\mathrm{h}}$ per ml. Finally, the total reactor volume was harvested. In this process a total amount of $21 \mathrm{~g} \mathrm{mAb}$ was produced.

From the monoclonal antibody and cell concentration data show'n in Fig. 5. the integral specific production rates for the monoclonal antibody have been calculated according to the following formula:

$q_{p}(t)=\frac{c_{p}(t)-c_{p}(t=0)}{\int_{11}^{1} x(t) \mathrm{d} t}$

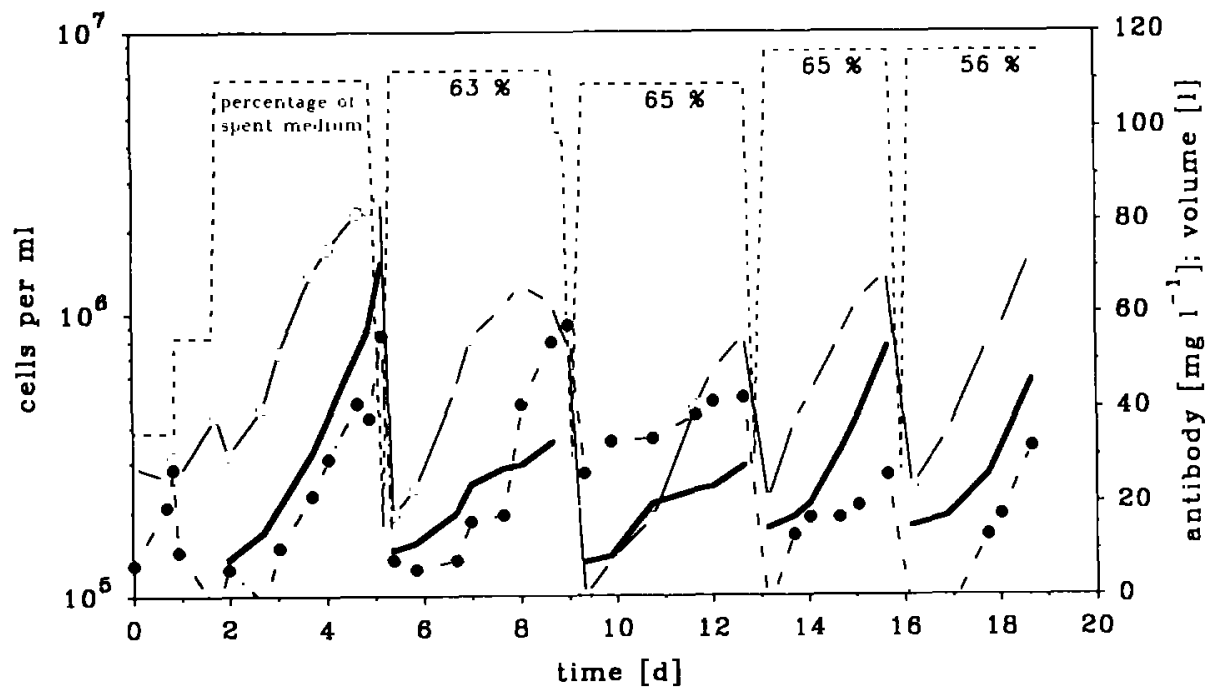

Fig. 5 The time course of the overall cultwation. Shoun are viable and dead cell numbers. the product concentrations in the bioreactor and the working volume. For each recycling process the percentage of the spent medium inoculum and recycled medium 1 s indicated. $\because$ vable cells; $\bullet$, dead cells; — antibody: . . . . . whlume. 

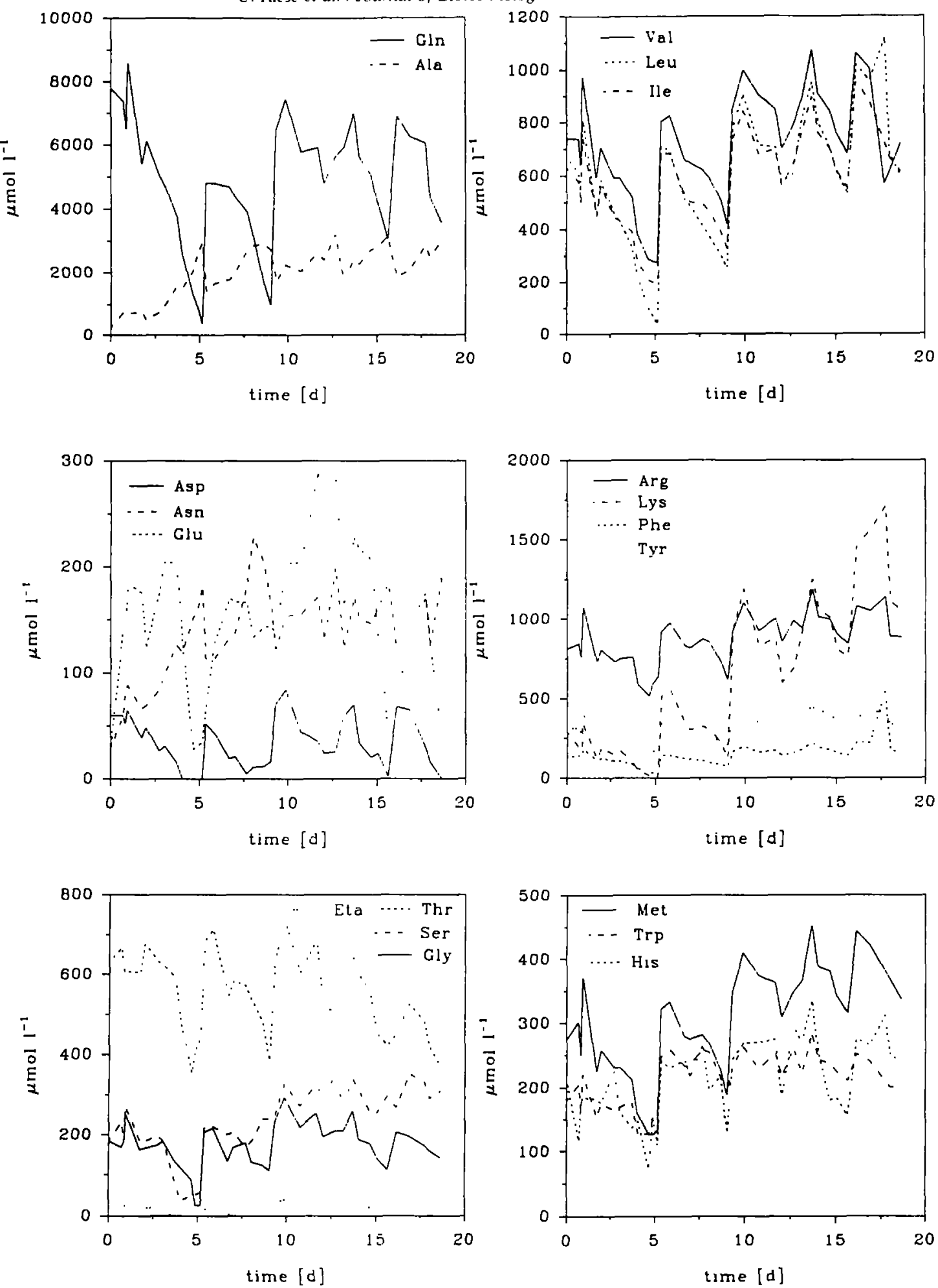

Fig. 6 . Concentration of amino acids in the bioreactor. By adding the fresh medium nutrient concentrate the consumed nutrients were refreshed at the beginning of each recycling process. 


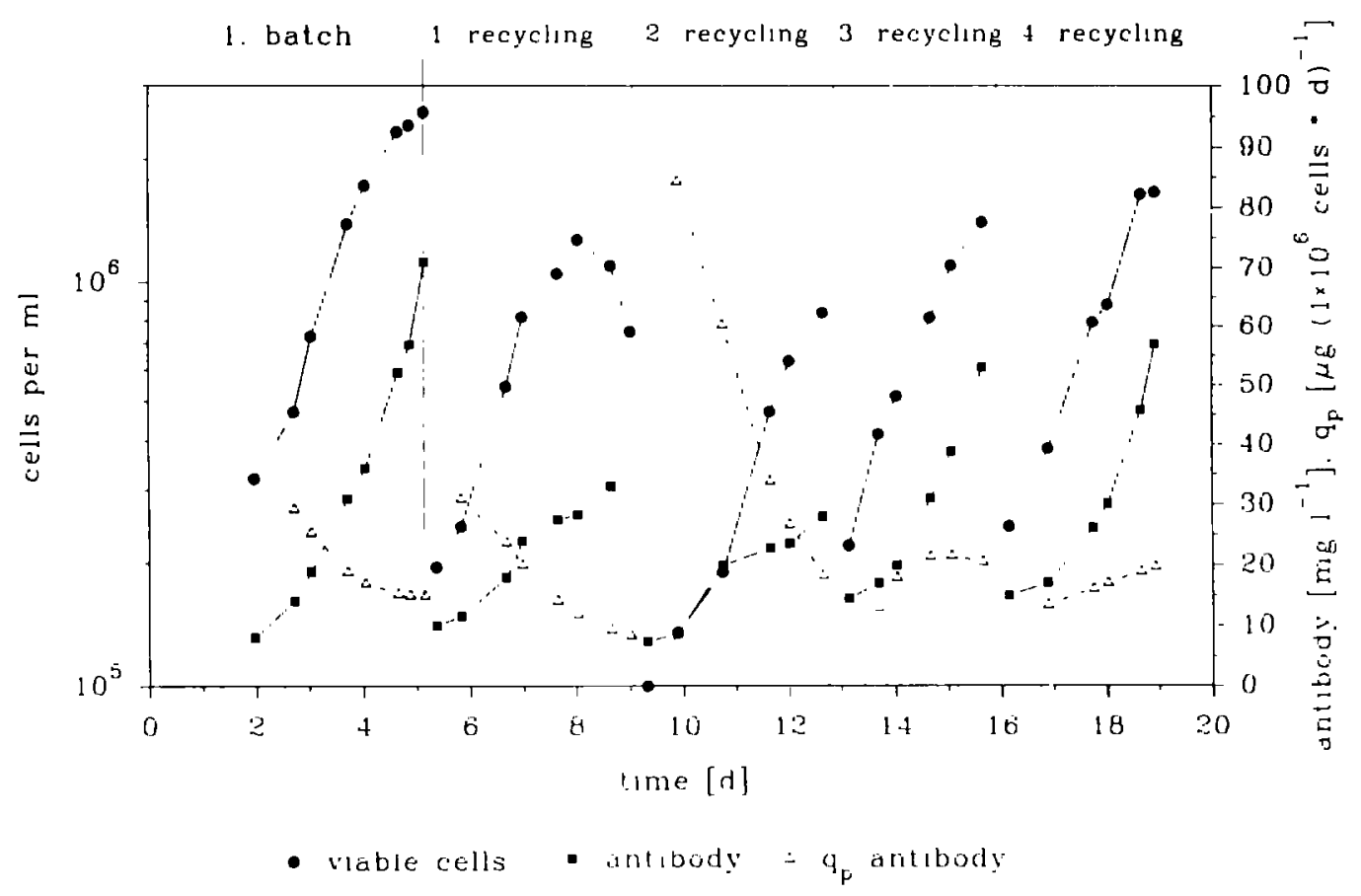

Fig. ${ }^{7}$. Integral specific production rates calculated by formula 11 during the fise batch processes calculated by integration of a

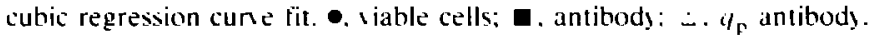

The results of the calculations are shown in Fig. 7 . The specific rates $\left(q_{\mathrm{p}}\right)$ could not be observed as constant during the batch process. In the initial batch and the following two repeated batches there was a decrease, where in contrast in the last two repeated batches we found an increase. The minima and maxima values are given in Table 3 where the apparent specific growth rates are also shown.

To characterize the efficiency of the recycling processes the ratio of antibody produced to the amount of fresh medium used have to be re- garded. The overall yield per batch $Y_{\mathrm{mixh}}$ (.) $(\mathrm{mg}$ mAb per litre fresh medium) is calculated as: [(final mAb concentration) - (initial mAb concentration)](batch volume)/(fresh medium volume):

$Y_{\text {man w.t }}=\left(c_{\text {tun.t1 }}-c_{\text {start }}\right) \frac{V_{\text {b.tuh }}}{V_{\text {iresh }}}$

The results of this calculations are listed in Table $t$ and given in Fig. 8 with cumulative amounts of antibody.

Table 4

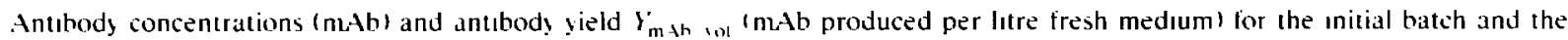
lour recycling processes

\begin{tabular}{|c|c|c|c|c|c|}
\hline Culture mode & $\begin{array}{l}\text { Initial mAb } \\
\text { concentration } \\
\left(\left.\mathrm{mg}\right|^{-1}\right)\end{array}$ & $\begin{array}{l}\text { Final mAb } \\
\text { concentration } \\
\left(\left.\mathrm{mg} \mathrm{|}\right|^{-1} \mid\right.\end{array}$ & $\begin{array}{l}\text { Batch volume } \\
\text { (I) }\end{array}$ & $\begin{array}{l}\text { Fresh medium } \\
\text { solume } \\
\text { (1) }\end{array}$ & $\begin{array}{l}\text { mAb produced } \\
\text { per I fresh medium } \\
\left(\mathrm{mg} \mathrm{I}^{-1}\right.\end{array}$ \\
\hline hatch & $\therefore$ & 71 & 111 & ! & 6.3 \\
\hline I recycling & 10 & 33 & 112 & 41 & $h_{2} . x$ \\
\hline 2 recicling & 74 & 28 & 1109 & $3 i$ & 54 \\
\hline 3 recsiclung & 14.5 & 53.8 & 116 & 41 & 111.2 \\
\hline 4 recucling & 14.9 & 5 & 116 & 51 & $95 . x$ \\
\hline
\end{tabular}




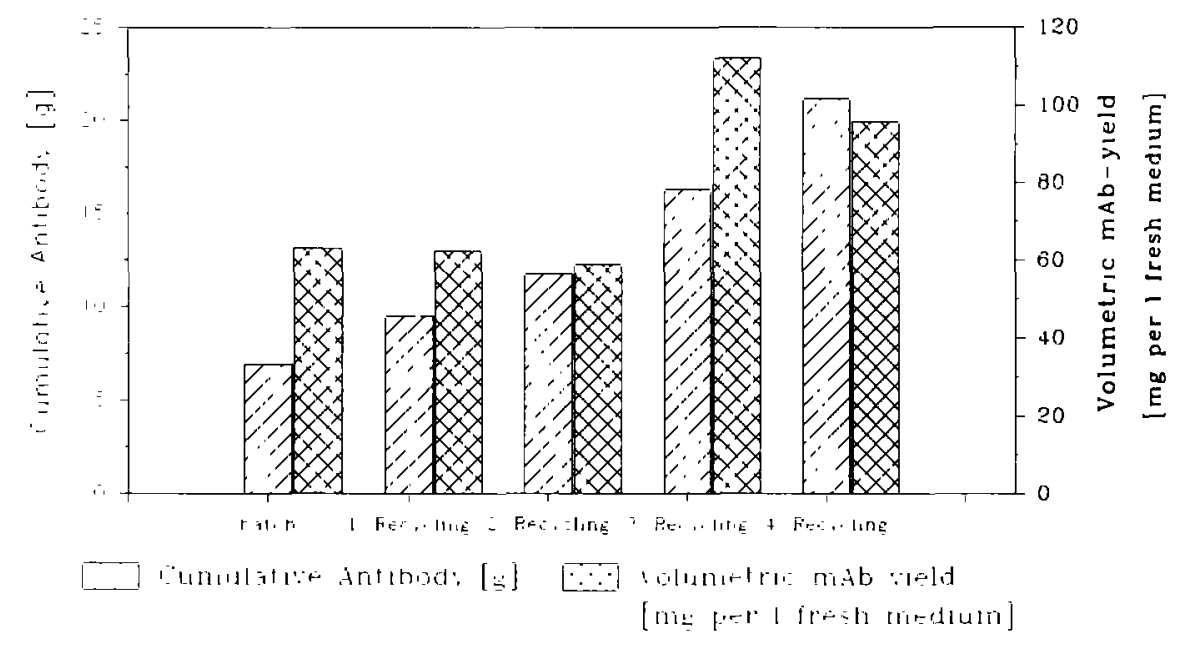

Fig. 8. Total amount of produced mAb (product yield). calculated yield coefficient.

In the batch process a yield of $63 \mathrm{mg} \mathrm{mAb}$ per 1 fresh medium was achieved. In the first and second recycling process the yield dropped under this level, but recovered in the third and fourth recy'cling process.

It can be seen from Fig. 5 and Table 4 that the cells may have adapted to the recycled medium. In the first and second recycling process the maximum viable cell density reached $1.3 \times 10^{\circ}$ viable cells per $\mathrm{ml}$ which is less than the viable cells of $2.6 \times 10^{\mathrm{h}} \mathrm{per} \mathrm{ml}$ in the initial batch. The product yield dropped under a lower level (62.8 $\mathrm{mg} \mathrm{l}^{-1}$ fresh medium) compared to the initial batch. However, in the following two recycling steps the viable cell density recovered and reached $1.7 \times 10^{\mathrm{h}}$ viable cells per $\mathrm{ml}$. Also the product yield increases up to $111.2 \mathrm{mg} \mathrm{mAb}$ per 1 fresh medium.
Regarding the cost of medium: For the initial batch process the medium costs have been calculated to $12.30 \mathrm{DM} \mathrm{I}^{-1}$ (Kempken et al., 1991). From Fig. 9 it can been seen that by starting of the recycling process the medium costs for the total process decreased to a level between $4.20 \mathrm{DM} \mathrm{I}^{-1}$ and $4.94 \mathrm{DM} \mathrm{I}^{-1}$.

The preparative membrane ion exchanger using the high flux system was used for rapid purification of one batch of the 100-I bioreactor. In four repeated runs one batch was purified using flow rates of $0.85-1.06 \mathrm{I} \mathrm{min}^{-1}$. These high flow rates resulted in a very high throughput of $3.9 \mathrm{~g} \mathrm{~h}^{-1}$. The binding rate was about $94^{\circ} ;$ and the recovery rates in excess of $82^{\circ}$ c (Table 5). It was possible to purify the whole batch without cleaning the module. Former investigation showed that one preparative module could bind up to

Table 5

Membrane chromatography with Sartobind S

\begin{tabular}{|c|c|c|c|c|c|c|c|c|}
\hline$\overline{\mathrm{No}}$ & $\begin{array}{l}\operatorname{IgG} \\
(\mathrm{mg})\end{array}$ & $\begin{array}{l}\text { Volume } \\
\text { (I) }\end{array}$ & $\begin{array}{l}\text { IgG } \\
\text { bound } \\
\left(\sigma_{c}\right)\end{array}$ & $\begin{array}{l}\text { Flou rate } \\
\left(1 \mathrm{~min}^{-1}\right)\end{array}$ & $\begin{array}{l}\text { Recoven } \\
\left(c^{(-)}\right)\end{array}$ & $\begin{array}{l}\text { Concen- } \\
\text { tration } \\
\text { factor }\end{array}$ & $\begin{array}{l}\text { Process } \\
\text { lime } \\
\text { (h) }\end{array}$ & $\begin{array}{l}\text { Throughput } \\
\left(\mathrm{gh}^{-1}\right)\end{array}$ \\
\hline 1 & 456 & 1.4 & 91 & 0.85 & 90 & 3.1 & 0.11 & 4.2 \\
\hline 2 & 489 & 1.5 & 91 & 0.85 & 84 & 4.0 & 0.11 &.$+{ }^{3}$ \\
\hline 3 & 391 & 1.2 & צئ9 & 11.85 & 75 & 3.0 & 0.11 & 3.6 \\
\hline 4 & 267 & 1.1 & 97 & 1.06 & 80 & 4.4 & 0.08 & 3 \\
\hline
\end{tabular}

Within minutes gram quantities of product could be purified in the HFS. The concentration factor was calculated by dividing the IgG concentration in the elution by the IgG concentration in the supernatant. The binding rate was about $94 \%$ and the recotery rates in excess of $8 ? \%$. The throughput was $3.9 \mathrm{~g} \mathrm{~h}^{-1}$. 


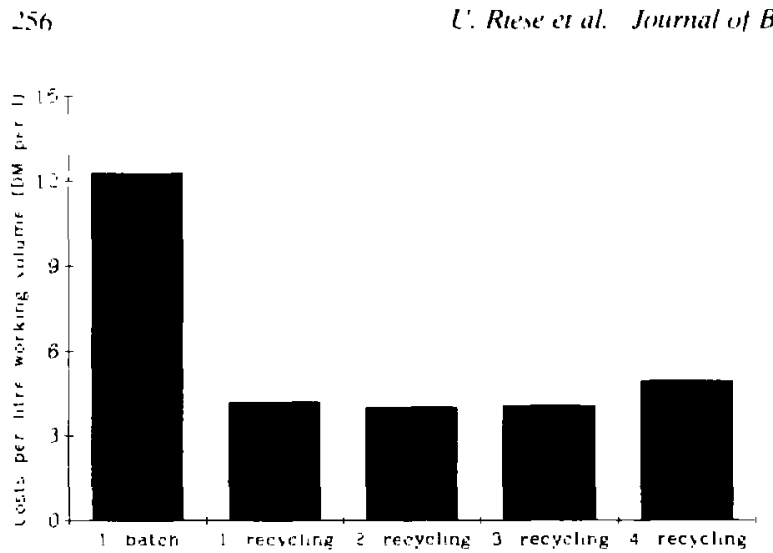

Fig. 4. Medium costs per litre working wolume for the intual hatch and the tollowing resycling proceses

$910 \mathrm{mg} \mathrm{mAb}$ without any loss in recovery (Lütkemeyer et al.. 1991) (greater amounts were not determined). The capacity of the membrane ion exchanger of $1 \mathrm{mg} \mathrm{IgG} \mathrm{per} \mathrm{cm}^{2}$ (equisalent to 50) $\mathrm{mg}$ IgG per $\mathrm{ml}$ hed volume), as determined with a single filter sheet $\left(12.56 \mathrm{~cm}^{2}\right.$ effective surfacel, is very high compared to filter materials of other suppliers.

Up to a flux rate of $5711 \mathrm{~m}^{-2} \mathrm{~h}^{-1}$ (maximum achiered by the systeml the binding of the mabs on the MIEX was better than $90 \%$. The concentration factor achieved by the MIEX is still somewhat unsatisfactory in comparison with a common ion exchanger, but optimization of the ion exchanger unit towards smaller elution solumes could change that. Up to now one MIEX unit was used 25 times without loss in binding capacity. recovery and flow rate. The main adrantage of the MIEX in comparison to ion exchanger based on gel matrices is the much higher throughput ( $>1.3$ times).

Final purification of the mAbs was carried out using a preparative gel filtration column. The elutions from the MIEX were applied directly. without prior concentration. to the gel filtration column and resulted in two distinct peaks. The second peak contained the purified mAbs (Fig. (1)1.

\section{Conclusions}

The experiment show's that it is possible to recycle up to $65 \%$ of spent medium. the specific

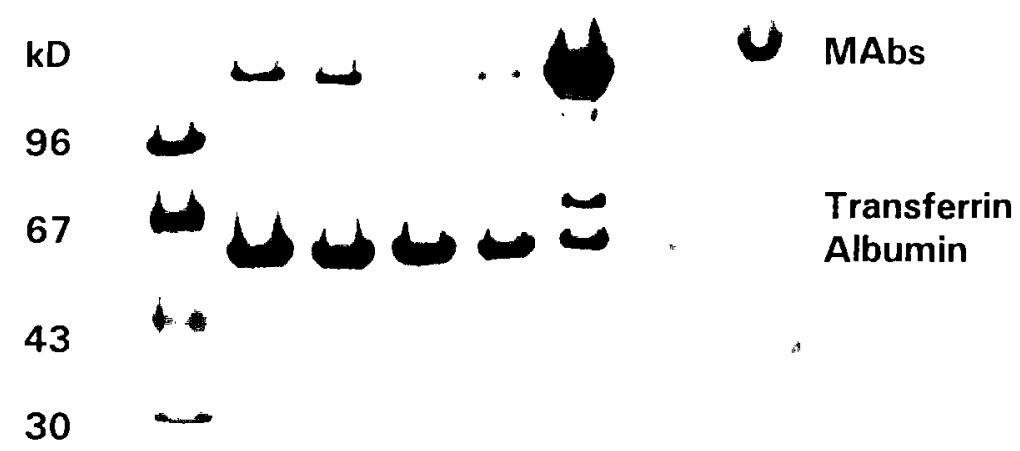

21

14

\section{$\begin{array}{llllllll}1 & 2 & 3 & 4 & 5 & 6 & 7 & 8\end{array}$}

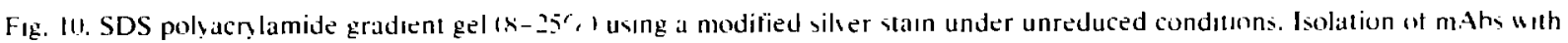
strong acidic membrane ion exchanger and gel tiltration. Lane 1. marker 14-46 kDa (reduced): lane 2, supernatant: lane 3. supernatant after salt reduction: lane 4 , unhound protems (MIIEX): lane 5. first wash (MIIEX): lane 6 . concentrated IgG (MIIEX). lane ${ }^{7}$. gel fïltration 1 peak: lane $\$$. gel filtration 2 peat. purified m. ths. 
antibody production pattern was only influenced when recycling started. The first recycling process shows that it is important to stop the batch at the exact point of no limitation. In the total process it was only necessary to use $281 \mathrm{I}$ of fresh medium instead of 563 I which would have to be used in a conventional repeated batch procedure. For the spent medium which was only supplemented with amino acids and glucose, $52 \%$ of the total medium costs were cut.

By medium recycling. $112 \mathrm{mg} \mathrm{mAb}$ per 1 fresh medium could be obtained, compared to $63 \mathrm{mg} \mathrm{mAb}$ per 1 fresh medium in the initial batch.

Compared to the batch culture, the specific productivity decreased in the first recycling process but recovered in the second and reached its peak value in the third. Therefore, an adaptation of the cells to the recycling is obvious.

Membrane ion exchangers are versatile tools for the concentration and purification of mAbs. The binding capacity and the recovery are similar to gel matrices. Using the high flux system very high throughput of the MIEX was demonstrated as the main advantage, which is easy to handle and can be used repeatedly.

\section{Acknowledgements}

This study was supported by the project 'Development of a procedure and a plant for the recirculation of nutrient media for animal cell culture' (BMFT project reference No. 031 9346A) of the German Federal Ministry of Science and Technology and by KabiPharmacia Bioscience Center (Sweden). We thank Ms. A. Stenner for her technical assistance.

\author{
Abbreviations and notations \\ $c_{\mathrm{p}} \quad$ product concentration $\left(\mathrm{mg} \mathrm{l}^{-1}\right)$ \\ $q_{\mathrm{p}} \quad$ specific production rate $\left(\mu \mathrm{g}\right.$ per $10^{\mathrm{b}}$ vi- \\ able cells per $d$ ) \\ $t$ time (d) \\ l. volume (l) \\ $x \quad$ viable cell concentration (cells per ml) \\ $Y_{\mathrm{m} . \mathrm{Ah} \text { s.l }}$ mAb yield (mg product per I) \\ DM Deutsche Mark \\ $\mathrm{d} t$ time interval \\ kDa kilo Dalton \\ $\mathrm{M} \quad \mathrm{mol} \mathrm{l}^{-1}$ \\ mAb monoclonal antibody \\ rpm rounds per min
}

\section{References}

Büntemejer. H. (198x) Entwıcklung eines Perfusionssystems zur kontinulerlichen Kultiverung tierischer Zellen in Suspension. PhD Thesis. University of Hannover, Hannover, Germany.

Büntemeyer, H., Lutkemeyer. D. and Lehmann. J. (1991) Optumization of serum free fermentation processes for antibody production. Cytotechnology 5, 57-67.

Kempken. R., Büntemeyer. H. and Lehmann. J. (1991) The medium cycle bioreactor (MCB): Monoclonal antibody production in a new economic system. Cytotechnolog 7 . 6.3-74.

Lutkemeyer. D.. Siu iora. S., Buntemeyer. H. and Lehmann, J. (1991) Microporous membrane ion exchanger for rapid purification of monoclonal antibodies. In. R.E. Spier and J.B. Griffiths (Eds.), Animal Cell Technology: Derelopments, Processes and Products. MacDonald. Butteruorths -Heinemann Lid.. pp. 613-618.

Munzert E. (1492) Langzeit-Mediumrecyclisierung. Im 2 I-Periusionsreaktor. Masster Thesis, University of Bielefeld. Bielefeld, Germany.

Mizrahi A. and Avihoo A. (1977) Grouth medium utilızation and its re-use for anımal cell cultures. Journal of Biological Siandardization 5. 31-.37. 